\title{
Indonesian Journal of Enviropmental Management and Sustainability
}

Research Paper

\section{Effectiveness Cream and Ointment of Spirulina platensis extract against amount of Fibroblas and Wound Area: Study on white rats whose skin is incised}

\author{
Bimby Irenesia ${ }^{1}$, Renni Yuniati ${ }^{2 *}$, Endang Mahati ${ }^{2}$ \\ ${ }^{1}$ Department of Biomedicine, School of medicine, Medical Faculty of Diponegoro University, Semarang, Central Java, Indonesia \\ ${ }^{2}$ Department of Dermatology-Venerology, Medical Faculty of Diponegoro University, Semarang, Central Java, Indonesia \\ ${ }^{2}$ Department of Farmacology, Medical Faculty of Diponegoro University, Semarang, Central Java, Indonesia \\ *Corresponding author e-mail: renniyuniati@yahoo.com
}

\begin{abstract}
Spirulina platensis has been well-known as an abundant protein and phycocyanin. Spirulina platensis has the effect of anti-inflammatory, so it is widely used to apply cosmetics and biomedicine in the healing process of wounds. To prove that the administration of an extract of Spirulina platensis can increase the number of fibroblasts and accelerate the wound healing process in Wistar rats with an incision on their skin. This study used a randomized post-test only control group design. The skins of thirty (30) male Wistar rats were incised. This treatment was divided into 4 groups, namely the group that received the $0,1 \%$ cream $(X 1)$ of S.platensis extract, and the group that was administered with the $0,1 \%$ ointment (X2) of S.platensis extract; the negative control group was only treated by a saline solution $(\mathrm{C} 1)$, and the positive control group was with the administration of Gentamycin $0,1 \%$ ointment $(\mathrm{C} 2)$. The total numbers of fibroblasts were examined on day 14 and calculated using the method of tissue biopsy and hematoxylin-eosin (HE) staining. The wound was checked after 14-day Data analysis was performed with a one-way ANOVA test and was continued by Post Hoc Test LSD. The total numbers of fibroblasts on day 14 from the group of $\mathrm{XI}, \mathrm{X} 2, \mathrm{C} 1$, and $\mathrm{C} 2$ were $15.00 ; 17,50 ; 3,83,10,33$ with $\mathrm{p}<0.001$. The average size of the wounds on day 14 from the groups of $X 1, X 2, C 1$, and $C 2$ was 551,$78 ; 435,76 ; 1795,95 ; 1193,57$ with $p<0.001$, respectively. Post Hoc Test results on the total number of fibroblasts and extensive wound area showed significant differences between them. Administration of the $0.1 \%$ ointment of Spirulina platensis extract believed to potentially increasing the number of fibroblasts and accelerate the process of wound healing.
\end{abstract}

Keywords

Spirulina platensis, fibroblasts, extensive wound area

Received: 3 June 2020, Accepted: 18 June 2020

https://doi.org/10.26554/ijems . 2020 .4 .2.39-42

\section{INTRODUCTION}

A wound is a form of tissue damage on the skin caused by contact with a heat source (such as chemicals, water, heat, fire, radiation, and electricity), including the preventive actions or changes in physiological conditions (Fithriani et al., 2015). A wound causes disturbance in the function and anatomical structure of the body. Normal wound undergoes a series of events that involves a process of wound healing. (Syarina et al., 2015)

Wound healing is a dynamic process that involves complex interactions between cellular, molecular, biochemical, and physiological activity that produces the regeneration and the replacement of injured connective tissues at the wound site. Connective tissue cells, which are very important in the remodeling and healing of the damaged tissue, are fibroblasts. Wound healing can be helped in the form of antiseptics, antibiotics, and wound care in general. While the treatments can be executed by giving drugs that are commercial or using alternative specialized materials that are founded in nature. (Syarina et al., 2015; Yu, 2017)

Natural products considered healthier and safer for the body. The World Health Organization estimated that $80 \%$ of the world population utilizes herbal medicine to maintain health. One of the commodities that have not yet been widely explored in Indonesia in terms of the development of herbal medicine is a microalga (Fithriani et al., 2015).

Algae has been a growing interest for the community as a drug and food, as it produces products that are harmless and nutritious to the health supplement market. One of the biodiversity examples of microalgae in Indonesia, which has various potency, is Spirulina platensis. (Fithriani et al., 2015; Syarina et al., 2015) Spirulina platensis is a blue-green 
alga that has a spiral-shaped filament.(Fithriani et al., 2015; Syarina et al., 2015; Somchit et al., 2014; Yu, 2017). Spirulina platensis contains protein, chlorophyll, carotenes, and phycobilin (phycocyanin, allophycocyanin, and phycoerythrin).(Somchit et al., 2014; Konícková et al., 2014; Ridlo et al., 2016; Jung et al., 2016; Gur et al., 2013)

Provision of packaged ointment, based on wound healing, is much quicker than the cream one - this is due to the fast absorption ability of the lotion. However, there has been no research data on the effectiveness of Spirulina platensis administered in the form of an ointment. Therefore, it is scientifically necessary to research the efficacy of the Spirulina platensis extract of lotion on the number of fibroblasts and extensive wound area on Wistar white rats.

\section{EXPERIMENTAL SECTION}

\subsection{Extracts of Spirulina platensis}

The S. platensis used in this study were obtained as S.platensis powder with US FDA registration number of 15594742028 and CERES number of 50OGA1200043 (9241). The powdered S.platensis microalgae was macerated in $95 \%$ ethanol solution with 1:10 concentration (one part of S.platensis powder macerated in 10 regions of $95 \%$ ethanol solution). The maceration process was done for five days in a glass container. The glass container was stirred every day to make sure the uniformity of the maceration process. After five days, the solution was filtered through Whatman, and was evaporated using a rotary evaporator machine at the ethanol boiling point temperature until a thick extract is obtained. This extract of S.platensis was used as the material in the subsequent tests, further explained below.

\subsection{Experimental Animals}

30 male Wistar rats aged 2-3 months were acclimatized for 7 days. After 7 days, the experimental animals were randomly divided into 4 groups and were performed an incision on the skin of their backs. The first treatment group was administered with the $0.1 \%$ cream of Spirulina platensis extracts. The second treatment group was treated with the $0.1 \%$ ointment of Spirulina platensis extracts for 14 days. Third, the negative control group was given only $0.9 \%$ saline solution. The fourth, the positive control group, was treated with Gentamycin 0,1\% ointment.

\subsection{Incision Procedure}

All rats were anesthetized with 0.1 cc ketamine per individual, then the backs of the rats were shaved with an area of $3 \mathrm{~cm} \mathrm{x} 2.5 \mathrm{~cm}$. Furthermore, an incision was made in the regions cut using a scalpel for $2 \mathrm{~cm}$-length and 0.25 cm-depth by stretching skins with the index finger, while thumbs of the left-hand acted as a relaxant and a suppressor. The scalpel was held using its handle with the right hand to form an angle of 300-400 to the skin. The incision was executed by pulling the scalpel towards the caudal. After that, the wound was closed adequately with gauze.

\subsection{The numbers of fibroblasts}

Observation of the histology was taken on day 14, which performed on the skin samples. Then, the calculation on the number of fibroblasts was observed in the histopathological examination with the skin preparations that have been stained with the HE staining. This calculation was by using a binocular microscope (Olympus CX-21, Japan) with an objective magnification of 40x. Imaging was performed using the video photo with three times of repetitions.

\subsection{Extensive Wound Area}

Extensive injuries areas were observed on day 14 preliminary, starting from the extracts' administration on the first day of treatment after the rats were incised. The size of the wounds was assessed by photographing them and then measuring them using Imageraster 3.

\subsection{Statistical Analysis}

The test used in this study was a One-Way ANOVA test to determine the difference in the number of fibroblasts and extensive wound area against all treatment groups. The magnitude of the difference in the name of fibroblasts and broad wound area on each group was necessary to perform further analysis using Post Hoc Test LSD. The significance value in this study was if the analysis variable has a value of $\mathrm{p}<0.05$. All statistical analysis was analyzed using the computer program SPSS 25.00.

\section{RESULTS AND DISCUSSION}

All used samples had similar average weights among the groups up to day 14. All treatment rats lived until the end of the study, then were terminated at the end.

Table 1. The numbers of fibroblasts

\begin{tabular}{ccccc}
\hline $\begin{array}{c}\text { Post-injury } \\
\text { day }\end{array}$ & Group & Mean & SD & p-value \\
\hline Day 14 & Negative control & 3.83 & 2.229 & $\mathrm{P}<0.001$ \\
& $\begin{array}{c}\text { Positive control } \\
\text { S.platensis extract } \\
\quad 0.1 \% \text { cream }\end{array}$ & 10.33 & 1.506 & \\
& $\begin{array}{c}\text { S.platensis extract } \\
0.1 \% \text { ointment }\end{array}$ & 17.50 & 2.757 & \\
& & & & \\
\hline
\end{tabular}

The analysis showed significant difference in the number of fibroblasts among the treatment groups on the 14th-day (Table 1), which had been discovered between the negative control group and the groups of $0.1 \%$ cream and $0.1 \%$ ointment of Spirulina platensis extracts. Also, the number of fibroblasts was also significantly different between the groups of $0.1 \%$ cream and $0.1 \%$ ointment of Spirulina platensis extracts and the positive control group.

The analysis exhibited a significant difference in wound size amongst the treatment groups on the 14th-day (Table 
Table 2. 14th-day of extensive wound area

\begin{tabular}{cccc}
\hline Group & Mean & SD & p-value \\
\hline Negative control & 1795,95 & 119,78 & $\mathrm{P}<0.001$ \\
Positive control & 1193,57 & 375,69 & \\
S.platensis extract & 5551,78 & 135,97 & \\
0.1\% cream & & & \\
S.platensis extract & 435,76 & 92,23 & \\
$0.1 \%$ ointment & & & \\
\hline
\end{tabular}

2 ), which had been disclosed between the negative control group and the groups of $0.1 \%$ cream and $0.1 \%$ ointment of Spirulina platensis extracts. In addition, the size of the cuts was also significantly different between the group of $0.1 \%$ cream and $0.1 \%$ ointment of Spirulina platensis extracts and the positive control group.

Fibroblasts have a very prominent role in the wound healing process, especially in the proliferative phase. They undergo proliferation process and collagen synthesis. The collagen fibers that are formed may lead to the existence of restraint reassembling the edges of the wound (Purnama and Ratnawulan, 2014; Palumpun et al., 2017; Sihotang and Yulianti, 2018).

In this study, it was revealed that the administration of the extract of Spirulina platensis might potentially increase the number of fibroblasts in mice that performed incision on their skins. The highest level of fibroblasts accordingly belonged to the group with the treatment of $0.1 \%$ ointment of Spirulina platensis extracts on day 14. The analysis showed a significant difference in the number of fibroblasts among the treatment groups on the 14th-day which had been discovered between the negative control group and the groups receiving $0.1 \%$ cream and $0.1 \%$ ointment of Spirulina platensis extracts. In addition, the number of fibroblasts was also significantly different between the group of $0.1 \%$ cream and $0.1 \%$ ointment of Spirulina platensis extracts and the positive control group. This result was in accordance with the studies done by Ibtisam Ahmed BaheuEldin et al, where Spirulina platensis significantly affects, in a positive way, the process of wound healing via formation of granulation tissues (the number of polymorphonuclear cells, lymphocytes, macrophages, and fibroblast) and enhances neovascularization in the area of the wounds.

Based on this research, the hypothesis was provenly admitted because the number of fibroblasts on the administration of the ointment extract of Spirulina platensis was much higher compared to the administration of Spirulina platensis extract cream. Wound healing is a dynamic process that involves complex interactions between cellular, molecular, biochemical, and physiological activity that produces the regeneration and replacement of injured connective tissues in the location of the wound (Gur et al., 2013; Pur- nama and Ratnawulan, 2014). There are 3 phases of the wound healing process: the inflammatory phase, proliferation phase, and maturation (remodeling) phase.(Purnama and Ratnawulan, 2014; Palumpun et al., 2017; Sihotang and Yulianti, 2018) Based on the research conducted by Syarina et al. (2015) stated that the water extract of Spirulina plants demonstrated the highest wound healing activity and may be considered a potential source of therapeutic agents to chronic wounds and related complications.

This study suggested that the administration of Spirulina platensis extract may promote the wound closure of mice that performed incision on their skins. The wound healing rate of mice in the group with $0.1 \%$ ointment of Spirulina platensis extracts, on day 14, had a faster healing activity compared to the group with $0,1 \%$ cream of Spirulina platensis extracts and the groups of positive control (KP) and negative control (KN). The analysis also exhibited a significant difference in terms of the size of the wounds amongst the treatment groups on the 14th-day which had been disclosed between the negative control group and the groups of $0.1 \%$ cream and $0.1 \%$ ointment of Spirulina platensis extracts. In addition, the size of the cuts was correspondingly significantly different between the groups of $0.1 \%$ cream and $0.1 \%$ ointment of Spirulina platensis extracts and the positive control group. This indicated that the extract of Spirulina platensis has a significant effect of anti-inflammatory to the wound healing acceleration. Similar reports by Seda Gunes et al. observed that the cell viability, the activity of wound healing and genotoxicity results reveals that the skin cream that was mixed with the ingredients of Spirulina platensis extracts was believed to be potential value in terms of cosmetic and biomedical application.

Based on this finding, the hypothesis was reportedly proved that the wound area on the administration of the ointment extract of Spirulina platensis was smaller compared to the administration of the cream extracts of Spirulina platensis.

\section{CONCLUSIONS}

The number of fibroblasts in the group receiving $0.1 \%$ ointment of Spirulina platensis extracts on day 14 was much more abundant than the group of $0.1 \%$ cream of Spirulina platensis extracts. However, no significant difference was revealed between both treatment groups. Extensive wound area in the group with $0.1 \%$ ointment of Spirulina platensis extracts was smaller in comparison with the group of $0.1 \%$ cream of Spirulina platensis extracts, and no significant difference was proven between both groups of treatment.

\section{REFERENCES}

Fithriani, D., S. Amini, S. Melanie, and R. Susilowati (2015). Uji Fitokimia, Kandungan Total Fenol Dan Aktivitas Antioksidan Mikroalga Spirulina Sp., Chlorella Sp., dan 
Nannochloropsis Sp. Jurnal Pascapanen dan Bioteknologi Kelautan dan Perikanan, 10(2); 101-109

Gur, C. S., D. K. Erdogan, I. Onbasılar, P. Atilla, N. Cakar, and I. D. Gurhan (2013). In vitro and in vivo investigations of the wound healing effect of crude Spirulina extract and C-phycocyanin. Journal of Medicinal Plants Research, 7(8); 425-433

Jung, S.-M., S. K. Min, H. C. Lee, Y. S. Kwon, M. H. Jung, and H. S. Shin (2016). Spirulina-PCL nanofiber wound dressing to improve cutaneous wound healing by enhancing antioxidative mechanism. Journal of Nanomaterials, 2016

Konícková, R., K. Vanková, J. Vaníková, K. Vánová, L. Muchová, I. Subhanová, M. Zadinová, J. Zelenka, A. Dvorák, M. Kolár, et al. (2014). Anti-cancer effects of blue-green alga Spirulina platensis, a natural source of bilirubin-like tetrapyrrolic compounds. Annals of Hepatology, 13(2); 273-283

Palumpun, E. F., A. A. Wiraguna, and W. Pangkahila (2017). Pemberian ekstrak daun sirih (Piper betle) secara topikal meningkatkan ketebalan epidermis, jumlah fibroblas, dan jumlah kolagen dalam proses penyembuhan luka pada tikus jantan galur Wistar (Rattus norvegicus). eBiomedik, $\mathbf{5}(1)$
Purnama, H. and S. Ratnawulan (2014). Review Sistematik: Proses Penyembuhan dan Perawatan Luka. Jurnal. Fakultas Farmasi. Bandung. Universitas Padjajaran

Ridlo, A., S. Sedjati, and E. Supriyantini (2016). Aktivitas Anti Oksidan Fikosianin Dari Spirulina Sp. Menggunakan Metode Transfer Elektron Dengan DPPH (1, 1-difenil-2pikrilhidrazil). Jurnal Kelautan Tropis, 18(2)

Sihotang, H. M. and H. Yulianti (2018). Faktor-Faktor Yang Mempengaruhi Proses Penyembuhan Luka Post Sectio Caesarea. Care: Jurnal Ilmiah Ilmu Kesehatan, 6(2); 175-183

Somchit, M. N., N. A. Mohamed, Z. Ahmad, Z. A. Zakaria, L. Shamsuddin, M. S. Omar-Fauzee, and A. A. Kadir (2014). Anti-inflammatory and anti-pyretic properties of Spirulina platensis and Spirulina lonar: a comparative study. Pak J Pharm Sci, 27(5); 1277-80

Syarina, P. N. A., G. Karthivashan, F. Abas, P. Arulselvan, and S. Fakurazi (2015). Wound healing potential of Spirulina platensis extracts on human dermal fibroblast cells. EXCLI journal, 14; 385

Yu, J. (2017). Application of an Ultrafine Shearing Method for the Extraction of C-Phycocyanin from Spirulina platensis. Molecules, 22(11); 2023 